\section{Origin of AIDS}

SIR-In their recent review article in Nature (3 October, p.395), Wong-Staal and Gallo proposed that the HTLV-I virus originated in Africa and was brought to other endemic areas by commercial and slave trading dating back to the sixteenth century.

If this is true, I fail to see how the HTLV-I virus could have reached Alaska and Northern Scandinavia where it has been detected, and southern Japan where it is endemic. Japan was virtually cut off economically and politically from the rest of the world until the latter part of the eighteenth century. There was hardly any commercial trade between Japan and Africa before the twentieth century.

It is also important to emphasize that the presence of the HTLV-I virus in the vast expanse of continental Asia cannot be ruled out due to lack of epidemiological studies in the area.

Recent studies by the same authors now show that retroviruses highly similar to the human acquired immune deficiency syndrome (AIDS) HTLV-III virus occur not only in African green monkeys and macaques but also in some flocks of European sheep'. These animals can all show AIDSlike symptoms with advanced infection. Hence the possibility of humans acquiring AIDS worldwide from animal sources cannot be overlooked. Indeed, such a possible origin of human AIDS has recently been proposed by Lewin'.

JOSEPH ROSENIOR

University of Toronto,

Charles H. Best Institute,

112 College Street.

Toronto, Ontario,

Canada MSG 1 L6

1. Gonda M A at al Scicuce 227, 173-177 (1985).

2. Lewin P.K (ait med Ass J 132 .1110(1985)

\section{Biotechnology aids}

SiR-In your report (Nature 6 June, p.448) on plans for the computing facilities at the European Molecular Biology Laboratory (EMBL), only passing reference was made to the "Biosequences" workshop held at Grottaferrata (near Rome) on 24-25 May.

EMBL's plans were one contribution in a lively and wide-ranging debate on criteria and guidelines for the selection, by the European Economic Community (EEC), of projects contributing to the development of user services and research infrastructure for biotechnology in Europe. The workshop, sponsored by EEC, the Italian National Research Council and the University of Bari and organized by the latter, was timely in relation to EEC's current funding programmes for bio-informatics and for the development of the market in high quality information services. It also offered interesting comparisons and contrast between the various national activities of the
United States, the United Kingdom, France, Japan, Italy and Ireland.

Of interest was the emphasis by both structural researchers (A. Lesk of MRC, Cambridge) and molecular evolutionists (C. Saccone of Bari, R. Grantham of Lyons) on the need for a comprehensive approach, integrating all the diverse sequence, structural and biological data available in constructing and refining models and hypotheses (Compare with Lesk. A. "Coordination of sequence data", Nature $314,318 ; 1985)$. The paper by $B$. Keil (Pasteur Institute) on the use of the proteolysis data bank to define the fixation sites of proteolytic enzymes illustrated the power of organized data.

These comprehensive and necessarily multidisciplinary approaches and the cost and difficulty of developing sophisticated and efficient software (for example $C$. Rawlings of ICRF on artificial intelligence approaches to structure prediction) and hardware (for example A. Coulson of Edinburgh on the application of distributed array processors to sequence comparison), lead to emphasis on better communication, networking and resource sharing between European centres. Training, users' clubs, electronic mail, software portability and on-line access were typical of the topics commended for support, complementing the centres and activities funded from national or EMBL resources. The workshop proceedings will shortly be available from the Research Directorate of the Commission of the European Communities (200 rue de la Loi, B-1049 Brussels).

Istituto Superiore di Sanita,

Laboratory of Cell Biology,

Viale Regina Elena 299.

Rome, Italy

University of Bari,

Deptartment of Biochemistry

and Molecular Biology,

Via Amendola 165/A

Bari, Italy

\section{Creationism unloved}

SiR-In his letter (Nature 316, 184; 1985) C.K. Pallaghy, a senior lecturer in the school of biological sciences, La Trobe University, attributes the paucity of overt support for creationism by bona fide academics in reputable scientific departments to hostility to creationists by the hierarchy of their institutions and by their colleagues, and to fear of loss of respect and prestige generally. This attitude to creationists is hardly surprising in view of the methods they and their organizations adopt in promoting their fundamentalist religious views under the guise of "creation science".

Not content that our taxes are being used, through school grants, to support their fundamentalist Christian schools. they lobby vigorously for "creation scien- ce" to be taught in the state schools and have already scored some success in Queensland. The creationists acute aversion to evolutionism is such that they claim the Genesis creation stories to be the literal truth, despite their marked resemblance to Babylonian myths and to the mixtures of guesswork, poetic fantasy and folklore compiled by other races to account for the origin of man. So it is that Pallaghy, replying to a critic, had a letter last year in the Melbourne Age containing the passage, "first, does he realize that Noah's ark was immense $(450 \times 75 \times 45$ feet)? Its tonnage would have supported 4,000 fully grown African elephant bulls There would have been plenty of room for all had God put young animals on board."

Everyone will agree with the creationists' right to believe whatever they like, but not with their wish to impose such beliefs on the young and vulnerable, in contradiction to the findings of the past several hundred years of intensely painstaking research - a priceless cultural heritage.

R.H. ClaRKE

Meteorology Department,

Melbourne University,

Rosanna,

Victoria 3084,

Australia

\section{PhD theses}

SIR-I wholeheartedly agree with Beverly Halstead (Nature 29 August, p.760) concerning the relatively trivial return of a British PhD thesis volume from the comparatively substantial cost (invested?) for the purpose of its production.

The advocated prerequisite for the $\mathrm{PhD}$ award of publication of scientific articles arising from the thesis material is, in fact. similar to the system operated by many universities and colleges in both Scandinavia and the United States, Indeed, some overseas establishments demand only that the material by published in a journal without requiring a formal bound volume. No doubt some would object to the adoption of such systems in this country but at least the various funding bodies would be able to assess the value of their investment more readily as well as providing additional incentives to the $\mathrm{PhD}$ candidate.

Incidentally, I was enlightened by $\mathrm{Be}$ verly Halstead's mention of costs for technical assistance during the period of postgraduate research. This clearly does not apply in every case since neither myself nor the postgraduate students in this and other departments were offered the benefit of technical assistance. We were simply informed that the $\mathrm{PhD}$ was supposed to be "an individual effort".

I.C. KILPATRICK

Uiversity of Bristol,

Department of Pharmacology,

Medical School.

University Walk,

Bristol BS8 1TD, UK 